\title{
1. Malthus's principle of population in Britain: restatement and antiquation
}

\section{Ryan Walter}

Malthus published his famous Essay on Population in 1798. Perhaps no other book has been so much discussed by persons who have never read it.

(Marshall and Marshall 1879, 29)

A similar sentiment to that which Alfred and Mary Marshall expressed above could be registered regarding those who have read Malthus's Essay independently of its time and place. In attempting to avoid this vice when approaching Malthus and his reception in Britain, two intellectual contexts will be foregrounded before all others. The first is the rational wing of Protestantism, reflecting Malthus's education at the dissenting academy in Warrington and at the hands of the Unitarian William Frend at Jesus College, Cambridge (James 1979, 19-21, 31-2). Thus, in lieu of relying on the notion of 'conservatism', Malthus can be assigned to a late Enlightenment that was Anglican and statist in nature, and which affirmed the need to submit to the established order in accord with a God-given reason, not to overthrow this order using a secular reason (Pocock 1994, 313; O'Flaherty 2016).

The second context in which to place Malthus overlaps with the first: the dispersed project to develop a 'science of politics', which ran from at least David Hume through David Ricardo to John Stuart Mill (Collini et al. 1983). The science of politics should not be confused with the political science that formed in the twentieth century and which continues today, for it belonged to an arrangement of knowledge that has now disappeared in which what we think of as sociology, economics, history, and philosophy were cross-pollinating, and value neutrality was no goal because it was taken for granted that 'science' was directed to shaping governmental action.

The combination of rational Protestantism and the science of politics gave Malthus's work much of its intellectual force. Yet Malthus also benefited from the political moment. As Sergio Cremaschi has described 
(2014), Malthus was elaborating a theodicy in which God created poverty to teach us moral virtue; such natural theology was a prestigious genre in which to write in 1798 and it was ideally suited for combating the rationalism of reformers. And rationalism had come to be seen as a malady in politics following the success of Edmund Burke's Reflections on the Revolution in France (1790). William Godwin (1793; 1797) was therefore fighting against the tide of British reaction with his peculiar brand of rationalism by prospecting startling advances in human nature, the proximate stimulant for Malthus's Essay on the Principle of Population (1798). ${ }^{1}$ Malthus's anti-utopian argument drew on an intensely theoretical form of reflection, however, and it was this style of speculation that had come under attack as Burke's fears seemed to be realised in the bloody course of the French Revolution (Stedman Jones 2004, 69-87). Obviously, as an Anglican divine employed by the established church, Malthus appeared less threatening than did other reformers sympathetic to relief for Dissenters and Catholics, but he was still portrayed as a theorist by certain enemies, a charge to which he evinced sensitivity throughout his career (see especially Malthus 1820 [1986], 5-18).

The initial reception of Malthus's work occurred in this complicated context. In short, political economy was a highly unstable element of British political discourse in the post-revolution period, and multiple factions were competing for control of its power. Indicating this complexity is the focus of Section 1.1, which also provides the opportunity to point the reader towards key landmarks in the scholarly literature on Malthus. From here the focus narrows to concentrate on the reception of Malthus's principle of population. Key to this story is the work of Malthus's friend and rival, David Ricardo (Section 1.2), along with James and John Stuart Mill (Section 1.3). These thinkers take centre stage because they decisively shaped the fortune of Malthus's arguments by stripping them of their theological components, restating them for their own purposes and joining them to divergent political visions. This process of transformation continued when the new economics developed by William Stanley Jevons and Alfred Marshall arrived at the turn of the twentieth century (Section 1.4), by which time the infrastructure of argument had changed so drastically that Malthus's Essay could only function as a venerable grandfather-text to respectfully reference, with his actual argumentation belonging to another world. 
The overall argument being advanced in this chapter is thus that Malthus's principle of population was subjected to restatement and transformation as it was received by intellectual contexts increasingly remote from his own, pointing to the short tenure of theodicy as a propaedeutic for political economy. The failure to appreciate this fact is largely responsible for the temptation to invoke Malthus as possessing continued relevance today. ${ }^{2}$ The long-term story to be told will therefore be familiar to historians of economic thought: just like Adam Smith's Wealth of Nations, Malthus's Essay was being reworked before its author was dead, and this process continued in evolving reception contexts that continually updated his arguments into forms that would have been increasingly unrecognisable to their creator were he to have lived to encounter these restatements. In this way, Malthus ceased to be the source of ideas on population before the end of the nineteenth century, but he was the figure in whose name they were articulated nevertheless. As Michel Foucault once said in relation to Machiavelli, 'the discourse does not stem from him, but it is through him that it is conducted' (2007, 243). This is a common theme in the chapters of this volume, and the British case, despite being the source context for Malthus's work, does not represent an exception.

\subsection{THEOLOGY, THE SCIENCE OF POLITICS, AND THE INITIAL RECEPTION OF MALTHUS}

In Malthus's Essay, happiness was not an open-ended vista, as it was in utilitarian thought, but circumscribed by the existence of evil. Poverty was one type of evil, and it was willed by God to rouse humankind from indolence and slavery to the passions; in reacting to this condition, humans shaped themselves for the next life. This was heterodox theology, and given dangerously clear expression in the following passage towards the close of the first edition of the Essay:

the impressions and excitements of this world are the instruments with which the supreme Being forms matter into mind; and that the necessity of constant exertion to avoid evil, and to pursue good, is the principal spring of these impressions and excitements, seems to smooth many of the difficulties that occur in a contemplation of human life; and appears to me, to give a

2 For the historiographical issues surrounding context and relevance in relation to Malthus, see my review of Cremaschi and Mayhew (Walter 2015). 
satisfactory reason for the existence of natural and moral evil; and, consequently, for that part of both ... which arises from the principle of population. (Malthus 1798 [1986], 137)

In other words, the principle of population was a structural feature of God's design, and the statesman therefore needed to respect it just as much as the utopian projector.

In a confessional state, this was a high-stakes move, and it drew forth a complex set of responses. As Patricia James describes in her seminal Population Malthus (1979, 116-26), one offending aspect of Malthus's text was his apparent denial of God's command to multiply, which also threatened to violate the old aim of national power through population (see Bashford and Chaplin 2016, 17-53). Yet, as Boyd Hilton claims in The Age of Atonement, Malthus held appeal for those who feared the tendency for political economy to be 'anti-landlord, anti-clerical, and viciously secular' $(1986,37)$. In other words, Malthus's achievement was too valuable for those of this view to ignore, prompting technical revisions to his theodicy by numerous writers who have been described as shaping a 'Christian political economy'. A.M.C. Waterman's work is crucial here, especially his Revolution, Economics and Religion (1991, 106-12). As the title indicates, the anti-revolutionary services that Malthus's political economy performed are central to explaining the uptake of Malthus's Essay, as per Hilton. But the need to maintain certain verities regarding the goodness of God also shaped the reception of Malthus's text, above all, Malthus's decision not to rely on the Fall to explain evil in the world but to implicitly lay the blame at God's feet instead, via the 'voluntarist' aspect of his theory.

The closely associated issue here was the possibility for natural theology and scripture to be arranged as rival modes of argument, with the latter of course available to be construed as containing a literal account of Adam's sin against God. In this setting, William Paley, a Cambridge moderate, was an invaluable convert for Malthus's cause, seemingly as early as his Natural Theology (1802), and this paved the way for John Bird Sumner's Treatise on the Records of Creation (1816) to restate Malthus's system in terms more acceptable to Anglican clergy by fusing it with Paley's account (Waterman 1991, 113-70). Before this, however, Malthus was attacked by evangelical critics for favouring reason over revelation, with his modifications in the second edition of the Essay mollifying but not removing the suspicions created by the original (Cremaschi 2014, 130-34). That these eddies eventually became calm is evidenced by Thomas Chalmers, an evangelical, and an ardent Malthusian, who gave these two sets of beliefs simultaneous expression in his 
publications, most notably in On Political Economy (1832), and through his preaching (Hilton 1986, 55-70).

A further group of note has been called the Oriel Noetics, centred on Oriel College, Oxford, who also combined natural theology and political economy. The most famous names include Edward Copleston, Richard Whately, and (with less theology) Nassau Senior (see Rashid 1977; Corsi 1987). Given their intellectual orientation, it is no surprise that they were open to Malthus's principle of population and his call to abolish the Poor Laws. The Noetics formed a key moment in the fortunes of Malthus's thought because they exerted tremendous influence on administration through their connections with church, government, and through educating the sons of the landed and parliamentary elite, manifested most significantly in the 1834 Poor Law (Mandler 1990). For this reason, it has been claimed that Malthus's population principle achieved purchase on the 'official mind' via its dissemination by Christian political economists until the 1850s (Hilton 2006, 337). It has also been suggested, however, that Christian political economy faded along with the threat that had called it into being: Jacobinism's challenge to the Anglican state was over by the 1830s, not least because in this decade the Anglican state managed to transform itself by emancipating Catholics, granting relief to Dissenters, and reforming Parliament (see Clark 2000).

That Malthus had sought and achieved traction with politicians points to one of the reasons why he was greeted with horror by Romantics such as Samuel Taylor Coleridge and Robert Southey. Southey's first engagement with Malthus, in 1803, when he reviewed the second edition of Malthus's Essay, reduced Malthus's achievement to 'the pomp of numerals and ratios', school-boy arithmetic (1803, 292-3). This attitude did not waver over the years, and the idea of using Malthus's arguments as the basis for legislative action was the persistent fear:

To legislate upon theories of population would be as absurd as if a physician upon some theory of pneumatics were to set respiration to music, and order all his patients to regulate their breathings by the time. You might as well attempt to regulate the seasons, or to legislate for hunger and thirst. (Southey 1816 [1832], 246)

A central point of repulsion was thus the scientific pretensions of political economy, which cloaked its real nature as just another form of metaphysics that was (in its Smithian and Ricardian forms) associated with Jacobinism.

Under the surface, however, Malthus and the Romantics had shared doubts regarding the effects of manufacturing on the moral character of 
the people, and they held a common belief that the landed interest played a special role in the life of the nation. As Donald Winch has explained in his masterful Riches and Poverty (1996, 288-348), the complexities of the context must be brought to view to understand the passion of the Romantic reaction against Malthus: most of the Romantics had imbibed Godwin early in their formation, whom Malthus had bested in debate and then ignored; ${ }^{3}$ Malthus's supposed hostility to the poor also offended, not least because it threatened to destroy paternal government; and Malthus's personal and intellectual imbrication with the Unitarians seemed to confirm his blasphemous intent in denying both the godliness of multiplying the species and locating the cause of poverty in the mechanisms of nature, not in human policy.

These sins did not bother the Edinburgh Review, the leading (or rather pioneering) periodical of its time (est. 1802). Malthus was given great status in its pages in the first decade of the new century, being invoked as an authority when rejecting pre-theoretical accounts, while it seems that Malthus himself was given the task of revealing the errors of William Spence's revival of physiocracy in Britain Independent of Commerce (1807) (see Fetter 1953, 246). This was as one would expect, given that Malthus was a moderate or 'Country' Whig, a position compatible with that held by the reviewers (see Fontana 1985, 112-46). More importantly, Malthus was open to rational reform and committed to political economy's role in pointing the way forward.

Yet Malthus did sin, in the eyes of the reviewers - in those of Francis Jeffrey and Francis Horner in particular - when he defended the Corn Laws. This fact, combined with J.R. McCulloch's control of the journal's political economy reviews from 1818, saw the publication become a Ricardian mouthpiece despite the taint of James Mill and Jeremy Bentham. The effects were serious for Malthus's reception, for the Edinburgh Review was a crucial pipeline into Whig thinking, and when its pages became closed to Malthus he was obliged to turn to the Tory Quarterly Review (Collini et al. 1983, 77-8, 88). While the consequences for the adoption of his principle of population were mitigated by its reworking by Ricardo and Mill - discussed in the following sections the same may not be said for the reception of other aspects of Malthus's thought, his treatment of agriculture vis-à-vis manufacturing above all. This fact sharpens the importance of the Christian political economy discussed above as a primary vehicle for Malthus's thought, and the importance we should attach to the weakening of that tradition by

3 For this devolution see Winch (1996, 223ff). 
mid-century, for this meant that Malthus's primary legacy was through recensions of his principle of population.

Before turning to this topic in relation to Ricardo, something should be said regarding the reception of Malthus in 'socialist' thought. In the British context, the utopian projector and philanthropist Robert Owen is important. Personally close with Malthus's antagonist Godwin, Owen developed an account of character as formed by circumstances, and this informed experiments in child education at New Lanark, where he owned and managed cotton mills (see Claeys 1989, 63-105). More important for the argument here, Owen articulated a critique of Malthusian political economy in texts such as A New View of Society (1813) and Moral Physiology (1834). The Owenite view was propagated through his 'Halls of Science' to thousands of people, including to Friedrich Engels when he was in Manchester, who also absorbed the lessons through Archibald Alison's Principles of Population (1840) and John Watts's The Facts and Fictions of Political Economists (1842) (Stedman Jones 2019, 7). Engels combined this Owenite critique of Malthus with a moral anthropology sourced from Feuerbach; Engels's work impressed Marx who then developed his own critique of political economy, which initially stayed close to Engels's account but became differentiated by the 1850s when Marx began attacking Malthus's population theory for conflating nature with the historical laws of capitalism (Stedman Jones 2019, 11-15). In short, the negative reception of Malthus played a significant role in the formation of Marxian political economy, albeit in a more complicated manner than the usual Marxist auto-histories suggest.

\subsection{RICARDO'S ADAPTATION OF MALTHUS}

It is common to treat Ricardo as the deductive theorist to Malthus's more inductive approach (see King 2013, 34-41). Yet this framing occludes the historical debate, since the opposition between deduction and induction postdates Ricardo's death (see Walter 2018). Nevertheless, the MalthusRicardo contest was shaped by rival conceptions of good theory, and the place of theology in political economy (Cremaschi 2017). As will be seen, Ricardo could import much of Malthus's argumentation regarding population-wealth dynamics while removing the theological underpinnings. This is an important step in the larger process being described in this chapter because it meant that variations of Malthus's principle of population came to be stated not as part of the effort to recover God's laws for governing humans on earth, but in the pursuit of knowledge of production and distribution. 
Ricardo began his publishing career in relation to the Bullion Controversy, but his key engagement with Malthus's principle of population came in his intensely theoretical Principles of Political Economy and Taxation (1817). ${ }^{4}$ When it came to wages, discussed in Chapter 5 of the Principles, 'On Wages', Ricardo followed the course set out in the chapter on value and construed the cost of labour in terms of labour. The key notion here was of labour's natural price, which he defined as the bundle of food and goods necessary for labourers to 'subsist and to perpetuate their race', as this was determined by 'habit' (Ricardo 1817 [2005], 93). So far, this is a straightforward adaptation of Malthus's arguments and language regarding population. Ricardo innovated, however, by defining his natural wage with reference to a steady population, and without reference to the demand for labour. Ricardo's decision reflected his focus on the increasing difficulty of food production, which continuously raised the natural price of labour. From here the core of Ricardo's arguments unfolded - declining profitability slowed a nation's progress, and eventually brought it to a halt.

Ricardo next distinguished this natural price for labour from its market price, which was the price actually paid for labour at a given point in time. His essential idea was that when the demand for labour was high, wages would also be high, above the natural price, which implied that the 'race' of labourers would reproduce itself beyond the stationary rate, or, in other words, population would grow, eventually increasing the supply so that wages were depressed back towards the natural price, or even below it for a period of time. This process more or less determined the 'general condition' of the laboring class - oscillating between 'flourishing' and 'wretched' (Ricardo 1817 [2005], 94, 102).5 Here, too, we can register an adaptation of Malthus's analysis.

Ricardo then complicated his process by introducing the distinction between the value and quantity of capital. Capital was the portion of a nation's wealth that set labour to work, consisting of food, clothing, necessaries, raw materials, tools, and machinery; its value was determined by the quantity of labour needed to produce it. Ricardo developed two scenarios to illustrate the importance of distinguishing between the value and quantity of capital. In the first scenario, capital increased in quantity and value, as when more food was produced but with more labour required per unit. In the second scenario, capital increased without its value increasing, as when more food was produced with the same

4 I take Terry Peach's (1993) account of Ricardo to be unsurpassed.

5 This has been a point of doctrinal dispute in the secondary literature - see Peach (1993, 104-11). 
quantity of labour per unit. In both scenarios, the wages of labour rose because there was greater demand for it, but only in the first case did the natural price of labour also rise - because the value of food had increased and food was a component of the bundle of wage goods (Ricardo 1817 [2005], 95).

Under the second scenario, the situation of the labourer was little improved because the increase in their wages was largely absorbed by the increase in their food bill. Ricardo was thus able to state the following conclusion: wages rose or fell in response to the supply and demand of labour, and in response to the price of commodities in the labourer's wage bundle, as defined by the habits of their time and place, but gradually rising due to increasing difficulty of production on the land (1817 [2005], 97). Because the population could only double in perhaps 25 years, while capital could double in far less time, the accumulation of capital was the key factor in the short term and population growth operated over a longer time scale (Ricardo 1817 [2005], 98, 101).

The effect of Ricardo's arguments was to conscript population to an argument regarding the declining fertility of land and the danger of rent to social progress. In this regard, it built on his earlier Essay on Profits (1815), which contained a blistering attack on landlords. In the course of affirming this analysis in his Principles, Ricardo also took the time to correct Malthus on rent in a dedicated chapter, 'Mr. Malthus's Opinions on Rent'. What Ricardo objected to was Malthus's claim in his Nature and Progress of Rent (1815) that rent ought to be understood as the creation of wealth. Ricardo worked through Malthus's list of reasons why the price of corn was higher than the cost of bringing it to market: the fecundity of the earth, that foodstuffs were peculiar because they created their own demand, and the scarcity of fertile land.

According to Ricardo, what this argumentation revealed was Malthus's incomplete understanding of the principle of rent, which arose because of the existence of different rates of profitability. The trouble with Malthus's presentation was that it averred the role of the 'absolute' fertility of the land, but this was incorrect. Rent was proportioned to the 'relative fertility' of the land, and this explained why the most fertile lands could at times bear but little rent (Ricardo 1817 [2005], 403-4). ${ }^{6}$ Ricardo then

6 In the third edition of the Principles, Ricardo added a footnote that acknowledged that Malthus had claimed to be misunderstood by Ricardo on this point (Malthus 1820 [1986], 122 at n15); Ricardo quoted Malthus again to show that this seemed to be the only possible interpretation that Malthus's words would bear, and limited himself to disputing the misinterpreted claim (1821 [2005], 404 at $\left.n^{*}\right)$. 
turned to Malthus's distinction between the laws regulating the rent of mines and the rent of land yielding the necessaries of life, predictably finding that '[t]his distinction does not appear to me to be well founded' (1817 [2005], 405). ${ }^{7}$ Ricardo came finally to Malthus's peculiar claim that food was special because it created its own demand. In a masterstroke, Ricardo bested Malthus with his own tools by using population theory to claim that food did not call forth increased population; capital played that role, via the demand for labour (1817 [2005], 406-7).

These skirmishes between Malthus and Ricardo represent a crucial piece of evidence for the larger argument being developed in this chapter, for it shows how the science of politics accommodated rival enterprises. Malthus relied on natural theology to make certain claims about the nature of the world while reconstructing the will of a benevolent God. Ricardo did not do this, and claimed to be isolating causes because that was the proper way of proceeding in science. In this setting, Ricardo was able to develop the intricate theoretical argumentation for which he is still famous today. In other words, Ricardo's reception of Malthus was shaped by his diverging style of intellectual comportment that bade fair to capture political economy, not least through his influence on James and John Stuart Mill.

\subsection{JAMES AND JOHN STUART MILL: THE MATURITY OF THE SCIENCE OF POLITICS}

John Stuart Mill's Principles of Political Economy (1848) bore some important debts to Ricardian political economy, but it is important to note that its structure derived from his father's Elements of Political Economy (1821), which was divided into four chapters: production, distribution, interchange, and consumption. This text was, ironically, produced by James Mill from his son's notes of their daily talks on political economy, and this structure was itself an adaptation of the structure of the second edition of J.B. Say's Traité d'économie Politique (1814). The point is that this architecture gave a coherence to political economy that was not to be found in the books of either Malthus or Ricardo (Tribe 2015, 61). Within this structure, what had been a theological argument could be reformulated as an aspect of distribution, that is, the topic of population could be treated in relation to wages. As we will see, both Mills exploited this freedom and detached population from Malthus's theological concerns

7 A point noticed by Malthus (1820 [1986], 119). 
while retaining selected aspects of his argument regarding wagepopulation dynamics.

Starting with James Mill, his Elements treated production as an outcome of labour that was set to work by capital, with the produce divided between capital and labour, even if wages were typically advanced to labour for the convenience of the worker. The size of the relative shares was determined by 'competition', allowing Mill to sidestep Ricardo's convoluted value metaphysics and the question of wage goods for an account of the supply and demand of labour. The result was to derive a 'law': the relative rates of increase of capital and labour determined the condition of the masses, and a poor condition was attended by poverty, misery, and vice (Mill 1821, 24-9). With this deft set of moves, Mill had secularised Malthus's argument, and replaced the population-food ratio with a capital-labour ratio.

More displacement was to come. Where Malthus had investigated the customs and institutions of countless nations and adduced rates of births and deaths, Mill disparaged such 'facts' in favour of developing a 'proof' from the known 'physiological constitution of the human female' as revealed by 'the sciences of physiology and comparative anatomy' (Mill 1821, 30-31). This was promising much, but it only issued in the claim that a fertile woman could produce one child per year between the ages of 20 and 40. By contrast, capital had a tendency to stagnate owing to the role of declining fertility on the land, and because the dispositions of human nature inhibited saving. In addition, the state had a limited capacity for influencing the accumulation of either population or capital (Mill 1821, 30-45). ${ }^{8}$ In Malthus's hands, the population-food ratio had permitted a reconstruction of the laws willed by God to govern humans on Earth; Mill's ratios served an account of the limits of governmental power, and identified the end game of human progress.

This last point perhaps represents the sharpest difference between the two thinkers. Where Malthus's aim was to lower the horizon for rational reform, and to reveal the salvific necessity of ethical self-government,

8 Mill's stance on contraception should be noted here. He was prepared to speak of 'superstition' interfering with the happiness that could otherwise be enjoyed from matrimony, and of 'expedients' that might be found to limit the number of births $(1821,44,53)$. This has typically been read as inimical to Malthus's theodicy because sexual restraint was one of the higher ethical demands in his system, and the means for civilising the earth (e.g., Winch 1996, 241-2). Yet the issue is more complicated, not least because of Malthus's shifting views, and his having weighed the danger to women posed by contraceptive techniques of the time (Cremaschi 2014, 168-79). 
Mill's argument pointed out a dilemma for utilitarian politics. Mill's central premise was that progress required a class of persons who were freed from manual labour by moderate fortunes, which gave them time for leisure and cultivation, assuming that they already possessed a first-rate education. It was this class who were most able to raise 'human happiness to its greatest height' (Mill 1821, 49). This fact might have pointed out a straightforward path to human happiness, but the complication arose because of the tendency for declining fertility on the land to act as a brake on progress, by lowering profits to the point where accumulation would cease to occur. The solution was for progress to halt before this point was reached, thus enabling the class of leisured men who lived off profits to be maximised:

The grand practical problem, therefore, is, to find the means of limiting the number of births. It has also appeared, that, beyond a certain state of density in the population, such as to afford in perfection the benefits of social intercourse and of combined labour, it is not desirable that population should increase. The precise problem, therefore, is, to find the means of limiting births to that number which is necessary to keep up the population, without increasing it. Were that accomplished, while the return to capital from the land was yet high, the reward of the labourer would be ample, and a large surplus would still remain. If the natural laws of distribution were allowed to operate freely, the greater part of this net produce would find its way, in moderate portions, into the hands of a numerous class of persons exempt from the necessity of labour, and placed in the most favourable circumstances both for the enjoyment of happiness, and for the highest intellectual and moral attainments. Society would thus be seen in its happiest state. (Mill 1821, $51-2)$

What should be underlined in this utilitarian puzzle is that it represents an early example of class eschatology. Where Malthus projected a struggle between food and population that was endless because the formation of the human soul needed indolence to be conquered by foresight and prudence, Mill's dynamic exhibited anxiety over the conditions and limits of progress. In the discussion of Marshall to follow shortly, we will see one of the more dramatic class eschatologies outside of Marxism: the abolition of the working class and the universalisation of the refined gentleman.

Turning now to the younger Mill and his Principles of Political Economy, published in 1848, we can see that Mill's debts to Ricardo are visible in his willingness to talk of the permanent values of commodities in relation to the cost of production, although Mill hedged his bets by also prospecting an analysis of supply and demand. Free trade and the application of European capital to the new world was expected to force 
down costs of production. Of course, the great exception to this trend was the cost of food, another Ricardian fixation, since land was in finite supply, although historically the price of food in England had been relatively flat owing to offsetting improvements in technology, as revealed by Thomas Tooke's price tables. The mechanism of adjustment between population and profits was also in the best tradition of Ricardian analysis, with an expanded population drawing less fertile land into cultivation, with the marginal unit of land setting profits for the entire industry because excess profits were absorbed as rent. Mill even defended Ricardo against the accusation of 'intellectual perverseness', affirming that the interests of landlords did not lie with technological improvement (1848 [1965b], 727-8).

A different set of debts was on display in Mill's 'Preliminary Remarks'. For despite the fact that Mill was one of the pioneers of the philosophy of science in this period and its central distinction between induction and deduction, ${ }^{9}$ he deployed the vocabulary of theory and practice when it came to construing the nature of political economy. $\mathrm{He}$ asserted it as a rule that in every branch of learning 'Practice long precedes Science', and in relation to political economy the science was 'extremely modern' while the practice was as old as human intercourse (Mill 1848 [1965a], 3). The breakthrough moment for the science was Adam Smith's identification of the 'Mercantile System' as having misled both 'theorists and practical politicians', and the success of 'Mercantile Theory' owed largely to the fact that it had infiltrated everyday discourse (Mill 1848 [1965a], 4, 7). The chief confusion was between public and private wealth - the former being defined by Mill as all useful things possessing exchangeable value (1848 [1965a], 13).

More telling was Mill's free borrowing from Smith's and Malthus's conjectural histories regarding the movement from the savage condition to commercial modernity. Mill began his account with hunters, as wealth consisted almost entirely in clothes, ornaments, weapons, and canoes (1848 [1965a], 10-11). The pastoral state followed as animals were domesticated, giving rise to inequality, leisure, and the ability to create and satisfy new wants for the first time. The shift to agriculture was driven by the limitations of relying on natural pasture, although in the medium term agricultural nations were vulnerable to the 'superfluous hordes' who remained tied to a nomadic life (Mill 1848 [1965a], 12).

9 Political economy was to adopt the 'concrete deductive method' (Mill 1843, 559-60). 
Despite these dangers, the agricultural state supported far greater population in comparison to the nomadic state, but at the cost of reduced leisure, with any agricultural surplus being extracted by a government that would have been legitimated by a religious or traditional sense of subordination. The surplus could then be used to support soldiers and a court, and luxury consumption, and on this foundation a mercantile class grew (Mill 1848 [1965a], 13-15). Such, we are told, was the general pattern for Asia. In Europe the pattern was different because the size of the communities was no more than that of the town, and land was equally divided among the families of the community, and hence its distribution was governed by familial not political dynamics, and there was consequently minimal need for strict ordering of the society; this fact, combined with the flow of ideas characteristic of Mediterranean life, produced a generalised appetite for wants and desires, in comparison to its confinement to courtly life in Asia.

The result was to raise nations of traders, although given to warfare because of population pressures inherent to early agricultural societies, often creating a military spirit in some of these early peoples, and in others the habit of purchasing the security with tribute to the warlike; Mill was rationalising ancient Greece and, as we know, the Greeks gave way to the Romans, on Mill's account because they failed to incorporate their conquests. Roman glory was thus inevitable because they did incorporate their subject populations, just as Roman decadence was inevitable as wealthy families engrossed the land and wasted its wealth on luxury. The Europe that was built on the ruins of the empire was composed of landlords and tenants, or serfs. Following Smith's account, Mill claimed that wealth accumulated in the towns, which stood as both refuges from the depredations of the lords and centres of artisan skill. Europe's towns were frugal savers who came to acquire land from the landlords, and the towns eventually emerged as engines of commercial progress for which Asia possessed no equivalent. As the disparity in public wealth grew, so too did the disparity in military might (Mill 1848 [1965a], 15-18).

Here we can see Mill's synthesis of Malthusian population dynamics in the Essay and Smith's account of the basis of government and the historical formation of town and country in Book III of Wealth of Nations. The punchline for Mill's political economy was that the production and distribution of wealth was subject to a variety of influences that conspired differently depending on time and place. As per Malthus, this diversity and the nature of the phenomena meant that political economy was a moral science: 
In so far as the economical condition of nations turns upon the state of physical knowledge, it is a subject for the physical sciences, and the arts founded on them. But in so far as the causes are moral or psychological, dependent on institutions and social relations, or on the principles of human nature, their investigation belongs not to physical, but to moral and social science, and is the object of what is called Political Economy. (Mill 1848 [1965a], 20-21)

Malthus would no doubt have enjoyed the fact that, at least on this point, Mill was not a Ricardian. If we take his analysis of capital as an example, then we see that Mill treated capital as savings from previous income, hence the size of the capital fund would depend in large part on the strength of the dispositions of those who saved, itself a function of the society's stage of civilisation, and of the individual's circumstances and their moral inventory. Sailors, for example, not being sure of their mortal existence the following year, were poor savers (1848 [1965a], 160-63). This fine-grained and (what we would call) sociological analysis further divided Mill from Ricardo and kept political economy in a historicalconjectural track. But what of Mill's treatment of labour?

If we turn to Chapter 10, 'Of the Law of the Increase of Labour', then the crucial factor to note is that Mill's first serious discussion of population occurred under the heading of production: the analysis of production and distribution had replaced both Malthus's theology and the use of Smith's Wealth of Nations as the template for a political economy text's table of contents. Production was taken to require labour, capital, and 'natural agents', meaning natural but finite in quantity and subject to private property rights (Mill 1848 [1965a], 153). When it came to labour, Mill declared that Malthus had excited discussions that had disseminated the truth, which allowed him to be brief in his treatment, which consisted in asserting a geometric power in population that was held back by 'causes' (replacing Malthus's 'checks', the term that Mill would nevertheless adopt later in his treatment of wages from the point of view of distribution). These 'causes' kept the population down to the level that society could support (1848 [1965a], 156). At this point, Mill's modifications were minor: Malthus's 'positive check' was given as war and disease, while the 'preventive check' was rendered as 'prudence' and 'social affections', and the progressive narrative was retained: as civilisation advanced the positive check gave way to the preventive check, which became stronger as one moved from the labouring class to the middle class:

In proportion as mankind rise above the condition of the beasts, population is restrained by the fear of want rather than by want itself. Even where there is 
no question of starvation, many are similarly acted upon by the apprehension of losing what have come to be regarded as the decencies of their situation in life ... Among the middle classes, in many individual instances, there is an additional restraint exercised from the desire of doing more than maintaining their circumstances - of improving them; but such a desire is rarely found, or rarely has that effect, in the labouring classes. If they can bring up a family as they were themselves brought up, even the prudent among them are usually satisfied. Too often they do not think even of that. (Mill 1848 [1965a], 157)

As Malthus and Ricardo held, commercial society was characterised by the fact that the subsistence wage for the working class included many commodities beyond what was needed for subsistence, and this was a species of 'voluntary prudence' that Malthus had discovered to be most widespread in Norway and Switzerland (Mill 1848 [1965a], 157).

Mill, however, adapted the emphasis on prudence by prospecting the idea that the state might also be called on to act prudently, for example, by not permitting marriage until the parties could provide evidence that a comfortable life was in prospect. In addition, the nation might be blessed with happy habits in this regard, such as the English custom of married labourers living in cottages, which were in short supply in the eighteenth century, and the practice of levying poor rates on the parish, which encouraged landowners to limit the supply of cottages (Mill 1848 [1965a], 158). What should be noted here is how a similar terrain to the one covered by Malthus was being prospected by Mill, but without the theological framework that was essential to Malthus's work. This fact introduced certain notes of despair into Mill's work, for where Malthus produced a theodicy that reconciled human reason to the existence of evil and misery because it was revealed to be a condition willed by a benevolent God, Mill had no such balm to apply. Consider this statement regarding the working class:

It is but rarely that improvements in the condition of the labouring classes do anything more than give a temporary margin, speedily filled up by an increase of their numbers. The use they commonly choose to make of any advantageous change in their circumstances, is to take it out in the form which, by augmenting the population, deprives the succeeding generation of the benefit. Unless, either by their general improvement in intellectual and moral culture, or at least by raising their habitual standard of comfortable living, they can be taught to make a better use of favourable circumstances, nothing permanent can be done for them. (Mill 1848 [1965a], 159)

This issue will be seen to have exercised Jevons and Marshall, too, but in a different intellectual setting. 
Turning to the other side of Mill's coin, distribution, his Malthusian inheritance was also put to work in relation to wages. Mill followed the example of Smith and treated wages as determined by the nature of the particular type of labour, and by forces operating on all types of labour. The second set of forces could be considered under the headings of custom and competition, but in commercial societies the former cause rarely operated unmolested by the latter, and hence could be set aside for purposes of exposition. 'Competition' of course meant supply and demand and, in relation to labour, population stood in for supply and circulating capital for demand; this capital might be called the 'wages-fund' without qualification except that it excluded wages that were not paid out of capital, that is, wages paid to unproductive labour, such as to soldiers and domestics (Mill 1848 [1965a], 356). Here, again, Malthus might have enjoyed Mill's desertion of the Ricardian banner.

Mill also departed from Ricardo regarding the stationary state - the point at which the labouring population would be stable because wages drew forth sufficient reproduction to maintain the labour force, which Ricardo had taken to exert gravitational force on wages (see Section 1.2, above). Crucial to Ricardo's argument was the claim that wages rose and fell with the price of food, but to this maxim Mill was only prepared to concede that it was 'true hypothetically, that is, granting the suppositions'; but such suppositions could not be granted when it came to 'application to practice' because the possession by labourers of a minimum wage below which they would not reproduce their numbers was not 'physical' but 'moral' in nature and therefore susceptible to change whenever the impulse to population overwhelmed the desire for comfort (1848 [1965a], 341). In these comments Mill repeated one of Malthus's trademark criticisms of Ricardian theory, but he departed from Malthus's stern paideia: the implication was not the need for moral discipline and prudence but alarm that 'all propositions ascribing a self-repairing quality to the calamities which befal the labouring classes' were 'practically of no validity' (1848 [1965a], 341). More plainly, the condition of the working classes could fall, and had fallen in England's history, as the taste for luxury was not a reliable safety net. Conversely, labour's condition would only rise in a permanent manner when it leapt ahead, as in France after the revolution, and a new generation was reared with higher expectations than the one before, or by a lasting shift in the ratio of capital to population.

Malthus's example of the United States as a place where the power of population could be unleashed owing to the abundance of land and capital was supplemented by Mill with 'the Australian colonies' (1848 [1965a], 343). Setting those rare cases aside, population was always 
inhibited either 'from Mr. Malthus's positive, or from his preventive check', and Mill insisted that the findings in the Essay regarding which check operated in any given nation could still be read profitably (1848 [1965a], 345), which fits with the evidence of Mill's borrowings from Malthus in his conjectural history of the earlier ages of the world. Mill also endorsed Malthus's general critique of the Poor Laws, writing that they encouraged 'improvidence' and 'recklessness' in the 'uncultivated mind' typical of agricultural labourers, such that England's population was largely repressed by the operation of customary and legal restraints among this class, and by 'prudential motives' among skilled artisans and the middle classes, while the new flows emanating from the countryside had mercifully been absorbed by England's growing towns (1848 [1965a], 346, 351). Not everybody, it seems, was capable of rising to prudential conduct, hence there was a standing rationale for state prudence. It is not clear how well this finding would have sat with Malthus, since it seems to foreclose on moral improvement from inner sources for an entire class, while Malthus's theology impugned the state when it frustrated God's government of souls - through ill-conceived institutions such as the Poor Laws - but did not instruct the state to assume the work of the deity.

In this regard, Mill insisted that the wretchedness of the populations in Dorsetshire and Bedfordshire ought to excite not compassion but serious thinking regarding the conditions that 'nature' had stipulated for their improvement, disregarding the popular smear, 'hard-hearted Malthusianism' (1848 [1965a], 352). Of course, the situation was not helped by the tendency for the working classes to hold erroneous notions regarding their own condition, spurred on in this regard by enemies of the Whig party, or by the fact that it was a popular sport to claim to have disproved Malthus and his supporters by misreading the meaning of his ratios, which Mill treated as an unfortunately chosen 'illustration' (1848 [1965a], 353). The hard reality was, according to Mill, that altering the ratio of population to capital represented the only practical mechanism for improving the condition of labourers over the long term, and that the sooner labour came to understand this aspect of their destiny, the better:

let us try to imagine what would happen if the idea became general among the labouring class, that the competition of too great numbers was the special cause of their poverty; so that every labourer looked (with Sismondi) upon every other who had more than the number of children which the circumstances of society allowed to each, as doing him a wrong - as filling up the place which he was entitled to share. (1848 [1965a], 371) 
Perhaps it is only necessary to mention the title of the chapter where Malthus registered an equivalent sentiment to see that this is a genuine inheritance, 'Of the Modes of Correcting the Prevailing Opinions on Population' (Book IV of Malthus 1826 [1986]). ${ }^{10}$

This entailed a complete rejection of all utopian schemes to redistribute wealth in perpetuity, which Mill took to be entailed by most proposals for a minimum wage, since there was no point in fixing a minimum wage above what would be determined by the wages-fund if one did not also guarantee employment at this wage. Guaranteed employment, for all, at a higher wage: such a situation would 'suspend all checks, both positive and preventive', unless the state also stipulated that 'no person shall be born without its consent' (Mill 1848 [1965a], 357-9). If the internal sources of prudence were removed, then they had to be replaced by external sources, such as restrictions on marriage or penalties for bringing forth children that one could not support. As this discussion suggests, Mill was sympathetic to Malthus's indictment of the Poor Laws, and it was left to the Commissioners to produce the 'collection of facts, experimentally ascertained in parishes' that revealed the compatibility of a right to relief based on need without undermining 'industry' and 'prudence' (1848 [1965a], 360). In short, the relief needed to be administered with a stick: accompanied by conditions that were disliked by the recipient of charity, especially regarding limitations on freedom and discipline. There was a cure, and it was the office of political economy to prescribe it.

This, of course, was the whole point of Malthus's Essay. Once again, however, Mill's idiom was not theology - he was not pointing out the Christian virtues that were revealed by the existence of poverty - but civilisational progress. Human progress was the story of civilisation mastering the animal instincts, and in this regard it had been so successful that some instincts were barely remembered (Mill 1848 [1965a], 367-8). In relation to population, however, civilisation could boast few victories because of the role of religion in treating the multiplication of the species as virtuous behaviour, and in forbidding scientific discussion of the issue in the name of a 'scrupulosity of speech' that screened out anything that might be construed as 'Malthusianism' (Mill 1848 [1965a], 368, 370). Mill predicted that civilisation might one day claim a victory here, too. It would require nothing less than labourers overcoming the 'uncultivated state of their intelligence' and 'poverty' to

10 Chapter 8 of Book IV in the second edition of the Essay, and Chapter 9 in the sixth edition. 
adopt 'in theory' a 'rational view of their own aggregate condition' (Mill 1848 [1965a], 374). If this sounds like Marxism, it was not: Mill had in mind a national education that would equip the working class with 'common sense' and 'practical judgement' (1848 [1965a], 375), not with historical materialism. Further, poverty was to be ended not by the working class taking control of the means of production, but by the state-led elimination of poverty for an entire generation, thereby raising its expectations for the future: the target was 'their intelligence and their poverty', not class consciousness, and the leading means was colonisation (Mill 1848 [1965a], 374). Finally, the agent of this change was no vanguard but a future class of 'politicians' who were prepared to engage in bold 'statesmanship' (Mill 1848 [1965a], 378). Poverty might represent the maximal point of difference between Mill and Marx.

Mill privileged distribution over production as the primary aim for the 'legislator', and this, in turn, was treated as primarily a function of the habits and moral bearing of the labouring class, as we have seen. When it came to the likely future of the labouring class, we find Mill developing these themes in Chapter VII of Book IV, 'On the Probable Futurity of the Labouring Classes'. This can similarly be understood as an inflection of Malthus's project, for the progressive impulse displaced the concern with recovering God's will, instead directing attention to social conditions and their amelioration. According to one account of the working class's future, which Mill termed 'the theory of dependence and protection', or the 'patriarchal or paternal system', the higher classes were to superintend the lower classes, providing morality and religion in a mood of 'affectionate tutelage' (1848 [1965b], 758, 759, 762).

Mill treated this ideal with some contempt, asserting that, in addition to whatever moral failings it might contain, it was historically outmoded by material changes in society, such as the geographical concentration of the working class, mobility through railways, and the dissemination of radical ideas through dissenting preachers. In short: 'The working classes have taken their interests into their own hands, and are perpetually showing that they think the interests of their employers not identical with their own, but opposite to them' (Mill 1848 [1965b], 762). In contradistinction, Mill insisted that the future in fact lay not with a regressive nostalgia for a lost past, but with progress by making the working class 'rational beings' through spontaneous 'mental development', education, and, possibly, the franchise (1848 [1965b], 763-4). The leading effect of this development would be that the working class would provide itself with the good sense needed to acquire providential habits of conduct, thereby restricting population, and, if joined with the entry of women into industrial occupations, then there was every reason to expect change 
in the ratio between population and capital (Mill 1848 [1965b], 765). Finally, workers' cooperatives might also determine the fate of both the working and middle classes by healing the breach between them (Mill 1848 [1965a], 1007-14). ${ }^{11}$ Thus, unlike Malthus, Mill was prepared to countenance institutional innovation to circumvent or modify conditions that had previously been perceived as natural laws.

\subsection{THE NEW SCIENCE: JEVONS AND MARSHALL}

In finally turning to William Stanley Jevons and Alfred Marshall, this chapter examines the fate of Malthus's ideas in a context that can no longer be thought of in terms of a 'science of politics' that encompassed distinct fields. Perhaps the most telling index of this change is the fact that both Jevons and Marshall had careers teaching economics: Jevons at Owens College, Manchester, and then University College London, while Marshall held posts at University College Bristol, Balliol College, Oxford, and Cambridge. In other words, economics was emerging as a new profession, certainly a distinct path of scholarship, largely driven by the self-specialisation of economists themselves (see Kadish and Tribe 1993). Jevons maintained a wide range of interests, and his work was premised on the utility of joining economics with mathematics, while Marshall had ambitions for the science, creating the British Economic Association and its Economic Journal, and an economics tripos. The economists had finally arrived in Britain, and an intellectual formation such as Malthus's - combining theology, political speculation, and Smith criticism - was no longer possible.

Jevons began his The Theory of Political Economy (1871) by declaring that he did not doubt the validity of 'many portions of Economical doctrine', above all, the 'Theories of Population and Rent' (1871, vi). Nevertheless, he doubted that his predecessors had arrived at 'the correct mode of treating the whole science', which could receive superior treatment in the 'form' of 'a Calculus of Pleasure and Pain' (Jevons 1871, vi-vii). In making this claim, Jevons was exploiting what he perceived as the proximity of political economy to statistical mechanics, with the aim of bringing mathematicians and political economists into contact (see

\footnotetext{
11 Note also that Mill came to modify his position on the so-called 'wages-fund', finding that the demand for labour was more variable than had been thought, and that this fact tilted analysis in favour of trade unionism. See Mill (1869a; 1869b).
} 
White 2005). Jevons accordingly innovated in his treatment of value, making it dependent upon utility not labour. ${ }^{12}$

In making this move, Jevons was obliged to combat the prejudices that he detected when it came to 'attempts to introduce the methods and language of mathematics into any branch of the moral sciences' (1871, 3 ). His premise was that it would prove impossible to arrive at true theory without the use of differential calculus because the questions of political economy related to complicated relations between quantities, for which the symbolic apparatus of mathematics was far superior to natural language (Jevons 1871, 5-6). The issue of obtaining 'precise data' was a separate matter, although in this regard Jevons insisted that even the data used in astronomy and physics were approximate, but this fact hardly impeded the progress of those sciences, since both developed their 'mathematical theories in advance of their data' (Jevons 1871, 6-7). In fact, Jevons was prepared to subscribe to John Stuart Mill's prescription of the Concrete Deductive Method for political economy, in his System of Logic. ${ }^{13}$ This entailed testing and applying the 'deductive science of Economy' using the 'purely inductive science of Statistics. Theory must be invested with the reality and life of fact' (Jevons 1871, 26).

As can be seen, even if Jevons judged Malthus's population doctrine to have been correct, the reception context was an ambitious reformulation of political economy using new methods, where this 'method talk' itself registered a change in political economy's self-understanding, since the old talk of 'theory and practice' that was shared across the moral sciences was being supplanted by a specialised second-order discourse that took method and epistemology as its central object (see Walter 2018). ${ }^{14}$ Jevons also mobilised a rival moral anthropology to what was found in Malthus. In particular, at certain moments Jevons appears to have had minimal commitments regarding human nature. He wrote, for example, that 'I should not for a moment think of claiming for the mind any accurate power of measuring and adding and subtracting feelings, so as to get an exact balance' (Jevons 1871, 20). Jevons also insisted that his premises were parsimonious, taking only '[a] few of the simplest principles or axioms concerning the nature of the human mind' as his starting point to produce a 'mechanics of human interest' $(1871,24)$.

\footnotetext{
12 Building on an earlier statement in Jevons $(1866,282)$.

13 Which Jevons termed the 'Complete Method', see Jevons (1870, 258). But note that Jevons was hostile towards Mill's work on logic, along with his political economy. See White and Inoue $(2009,420)$.

14 Note also that Jevons made contributions to this field. See especially Jevons (1874).
} 
This owed in large part to the fact that Jevons assumed that each individual mind was inscrutable to every other mind, and that his political economy dealt with aggregates of inscrutable individuals in the pursuit of general laws that held at the level of wide averages but were indeterminate at the level of individuals (Jevons 1871, 21-3). Thus, although he acknowledged his debts to utilitarian theory, Bentham foremost, but also William Paley and Alexander Bain (Jevons 1871, 27-32), Jevons should not be read as a moral philosopher in the same way that Malthus might be profitably approached through this frame because his theory was not prescribing the good life but was directed at a smaller target: investigating those situations where pleasures had been more or less equal, after which some disturbing element was introduced.

With these points in mind, we can now ask: what did Jevons make of Malthus's population doctrine? As noted above, Jevons did not doubt its truth. He did, however, eject it from the field, writing that it 'forms no part of the direct problem of Economy', because that problem was to assume population and capital as given stocks and then determine how to maximise the utility of output (Jevons 1871, 255). It followed that to investigate changes in population amounted to respecifying the constraints of the problem. Rarely has there been such a clear example of how the rise and fall of theoretical questions is driven by the framework that posits them.

Jevons did, however, take the opportunity to inveigh against the so-called wages-fund, by which the average rate of wages was obtained by dividing the amount of capital available for paying wages by the labour force $(1871,256)$. In dubious reliance on John Stuart Mill, ${ }^{15}$ Jevons asserted that this was no answer at all, since the quantity of capital brought forth was actually a question to be investigated because it depended on interest rates and other factors, above all, anticipated profits. Further, Ricardo's claim that profits were the residual that remained after wages were paid was, according to Jevons, simply an allegation, as was Ricardo's assertion of a rate of wages that produced a steady population of workers. It was rather the case that entrepreneurs obtained capital and ventured on uncertain projects, buying labour as they needed, and receiving whatever profits eventuated, to then face heightened or lessened competition in subsequent production runs as the profits were strong or weak. Thus, and most significantly for the argument here, Jevons doubted that the necessaries of life could be defined such that changes in wages

15 For Mill's point was simply that underemployment was possible for a variety of reasons (1848 [1965a], 80-82). 
could be taken to induce compensating changes in population. Instead, Jevons prospected an analysis of the demand and supply for labour on an industry-by-industry basis $(1871,258-62)$.

The leading consequence was that the only use that might legitimately be made of the wages-fund concept was temporary in nature: given a certain quantity of capital that had been called forth by anticipations of certain profits, the supply of the relevant type of labour would be fixed in the short term, allowing the wage rate to emerge as a ratio. The wages-fund was therefore to be used on an industry-specific basis, and in the short term only. This was a belittling restatement of Malthus's discovery, and it is fitting that Jevons concluded his treatise by reflecting on the 'Noxious Influence of Authority' and its excessive influence in the face of 'experience and reason' (Jevons 1871, 265, 267). Jevons's new science was a toxic environment for Malthus's political economy.

Finally, Jevons's Political Economy (1878) is a revealing text because in it he described the purpose behind his 'small text-book' as expressing 'the truths of Political Economy into a form suitable for elementary instruction', drawing on his own teaching to 'pupil-teachers' when Cobden Lecturer on Political Economy in Manchester (1878, 5-6). The text therefore represents a statement of what Jevons thought was settled knowledge, and in a manner that was intended to be accessible. This was taken to be an invaluable service for society, in the tradition of Harriet Martineau, because all adults were obliged to make decisions regarding money and resources, and most did so on the basis of a false political economy that they simply constructed for themselves without ever studying the science, in a manner that no right-thinking person would presume to do regarding other sciences such as chemistry (Jevons 1878, $5,8,11)$. In short, the people needed to understand that political economy was a specialist field, yet a knowledge of its basics was indispensable for everybody.

Reactivating an old understanding, Jevons defined political economy as the study of the causes that render one nation wealthier than another, and located it in relation to other social sciences that were also indispensable to human welfare - jurisprudence, political philosophy, and statistics. Above all, political economy was different because it specialised in the study of wealth, and this reflected the fact that in learning we must do one thing at a time. We cannot learn the social sciences all at the same time' (Jevons 1878, 8). This registers a break with the conception underlying Malthus's political economy, which did act as a clearing house for other forms of knowledge, in the same manner that Dugald Stewart used political economy as a master science. The 'science of 
politics' had been replaced by a map of knowledge that more closely resembled the one we occupy today.

As with Mill, Jevons set out the functions of government by distinguishing between 'optional' and 'necessary' functions (1878, 123). His list was also similar to Mill's, treating defence and law as essential, while weights and measures, roads, and a postal service were optional, and involved judgement: 'Each case has thus to be judged upon its own merits, and all that the political economist can do is to point out the general advantages and disadvantages of government management' (Jevons 1878, 124). The disadvantages of government management were said to derive from its presumed inefficiency compared to private activity, especially because it was both difficult and costly to dismiss government workers (Jevons 1878, 125-6). This style of assessing the role of the state in what we think of as the economy was alien to Malthus's work, for political discourse had not come to be organised around the distinction between government interference and non-interference but continued to operate with older notions, in the case of Malthus, of constitutional balance and the country gentleman's special role in its preservation.

The significance of this shift in political discourse can be estimated by noting Jevons's comments on protection and free trade. He claimed that the use of taxation to provide protection to domestic manufacturers was driven by the self-interest of those manufacturers, and by the old phenomenon of 'national pride and animosity' (Jevons 1878, 131). The task of the political economist, however, was to rise above the interests of any particular class and serve the entire population. In relation to wealth - the goal superintended by political economy - foreign competition produced more goods at a lower price. Whatever was imported would be paid for by exports, hence Jevons claimed that foreign trade organised internal trade in the optimal manner - by encouraging the nation to export those goods which it was most suited to produce $(1878,132-3)$. Where Malthus had treated wealth as a subordinate ingredient to state happiness compared to a steady food supply in his The Importation of Foreign Corn (1815), Jevons was prepared to isolate wealth. ${ }^{16}$ Once more, the context of creeping specialisation must be foregrounded.

Turning now to Marshall, a sense of his intellectual context and hence the terms of his engagement with Malthus can be given by beginning with Marshall's The Future of the Working Classes (1873), based on a

16 But note a more complicated approach to these issues in The Coal Question (1865) and The State in Relation to Labour (1882). 
paper that he read to the Cambridge Reform Club in November 1873. ${ }^{17}$ Marshall's answer was as much moral catechism as it was economic analysis, for he imagined the progressive obliteration of the distinction between workers and gentlemen through the moral improvement of the former's 'inner life' until 'the working classes have been abolished' $(1873,16)$. While acknowledging the difficulty of defining the working class, he settled on the claim that the working class could be identified with reference to the effects of their work on their moral character some tasks kept the character of men 'rude and coarse' while others promoted 'culture and refinement of character' by activating the powers of the mind through sympathetic social intercourse with other refined persons (Marshall 1873, 5). (In consequence, wealth could not be taken to define class, although it would normally be a reliable index.) Marshall used this precept to locate the artisan as higher than the mason both in terms of refinement and regarding their prospects for becoming a gentleman. The key difference was that a gentleman cultivated his moral person, which required leisure and energy for learning and culture, beyond the grasp of the mason after a day's labour because his body would be exhausted and his mind dulled owing to the impoverishment of human blood after sustained exertion, which also made him vulnerable to the pleasures of drink and raucousness (Marshall 1873, 6-7).

In opposition to the socialist plan to subvert the existing order, Marshall imagined a future in which all jobs were consistent with the gentleman's needs for self-cultivation. Of course, there would still be disagreeable work, but it would be rewarded by higher wages, making it possible to work less, and everyone would benefit from a worthy education in youth. The reduction in hours and the increase in wages would be more than offset by the advance of technology, allowing steam to replace human muscle, and constant machine production would be paired with short shifts of perhaps six hours each, thus forestalling the exhaustion of the body and stupefaction of the mind. Technology thus emerges as a central part of the solution. On the other hand, the present condition of labourers was caused by their wilful self-competition: workers sacrificed the means of their own improvement for higher wages, which were then wasted through improvident marriages that brought forth sickly children that compelled 'Nature with her sorrowful but stern hands to thin out the young lives before they grow up to

17 For a detailed treatment of the intellectual context surrounding this text, including Marshall's relationship with J.S. Mill, see the invaluable discussion by Simon J. Cook (2009, 245-58). 
misery' (Marshall 1873, 13). Education would impress upon future fathers their duty to give their children a better education than they themselves had received - the same principle would later be articulated in Economics of Industry - and to internalise social sanctions for failing to meet this burden by marrying improvidently, a norm that would be reinforced by the state's treatment of poor parenting as a form of treason $(1873,13,15)$.

Two points should be made about Marshall's account in relation to Malthus's paideia. First, work was mythologised as a form of selfimprovement, which created the necessity of creating good work for all. As Marshall wrote,

Work, in its best sense, the healthy energetic exercise of faculties, is the aim of life, is life itself; and in this sense every one would be a worker more completely than now ... In the bad sense, in which work crushes a man's life, it would be regarded as a wrong. $(1873,13)$

Second, in one sense Malthus and Marshall both construed progress in terms of moral improvement. However, in Marshall's hands the telos for each individual was not to be a good Christian displaying the virtues and mastery of the passions necessary to enter the kingdom of heaven, but to be a gentleman. In other words, and in opposition to Malthus, the idea was to eliminate the working class. Marshall could imagine this future because he did not think of the problem in terms of finite resources - for he assumed that technology would resolve this issue - but in relation to moral qualities that could largely be dispensed through social arrangements such as national education. From Malthus to Marshall: from poverty to gentility, and from the school of God to the school of the state.

The same impression emerges from Economics of Industry, which Marshall co-authored with his wife, née Mary Paley (Marshall and Marshall 1879). This was a pedagogical text, written at the request of Cambridge University extension lecturers, and so it is like Jevons's text in offering insight into what was considered appropriate to be taught as firm knowledge. Regarding Malthus, the key discussion is found in Chapter 5, which bore the title 'Growth of Population. Malthus. Poor Laws'. The Marshalls produced a table revealing that the exponential growth of population from even a single pair would cover the surface of the earth many times over in only 3000 years. Hence, he concluded, population must be routinely receiving a 'check', one that varied with time and place. Malthus's research is glossed here in barely a page - it had received four chapters in the first edition of Malthus's Essay and 22 chapters in the sixth edition - and his demonstration of the positive 
check's role is described as an exemplar of 'patient and hard-working science' (Marshall and Marshall 1879, 30). What for Malthus had been a key means for adducing evidence and making his argument was now a mere illustration, and Malthus's theodicy had been redescribed as patient science. Similarly, Malthus's central conclusion was presented as follows:

The natural propensities of man will cause population to increase as fast or faster than the means of supporting them; therefore the efforts of the legislator and of the moralist should be directed towards improving the character of the people; and towards discouraging rather than encouraging a rapid increase of numbers. Accordingly he urged 'moral self-restraint' as a 'Preventive Check' to the excessive growth of population. (Marshall and Marshall 1879, 30)

What can be noticed yet again is that the theological components of Malthus's work had been removed; what was in fact the recovery of God's laws for the government of humans on earth to form them for a life to come had been redescribed as empirical science.

This is not to say that the text did not bear marks of a normative agenda. In the first place, the expansion of the 'English race' over the world via the British empire is seen to be a positive development because it foreclosed the peopling of the earth by inferior races, such as the 'spiritless' Chinese (Marshall and Marshall 1879, 31). Further, the following principle is the leading means for human progress and for banishing the spectre of Malthusianism: 'Just as a man who has borrowed money is bound to pay it back with interest, so a man is bound to give his children an education better and more thorough than he has himself received' (Marshall and Marshall 1879, 32). Until that principle became active, there was a safety net through the 'Standard of Comfort' - the material standard below which the working class would not marry (Marshall and Marshall 1879, 28). From here the 'Law of Population' is derived - that a rise in income is either absorbed and so raises the standard of comfort for that class, or leads to increased population growth. As the working class came to imbibe Marshall's precept regarding generational progress, rises in income would be absorbed through rising standards of comfort, not through an increasing rate of population growth. Once again, progress would be a socio-intellectual achievement, lacking the ethical and theological content of Malthus's vision.

This account needs to be complicated in view of the treatment of Malthus in Marshall's Principles of Economics, first published in 1890, the eighth edition appearing in 1920. As is well known, Marshall's thinking had developed between these two texts, not least by his having broken away from earlier influences such as J.S. Mill. The key discussion 
comes in Book IV, concerning agents of production, with Chapters 4 and 5 titled, 'The Growth of Population' and 'The Health and Strength of the Population', respectively. Marshall glossed Malthus's argument as consisting of three parts: that the supply of labour was controlled by positive and preventive checks, that the demand for labour faced constraints from the food supply, and that Malthus accordingly argued for delayed and prudential marriages. In Marshall's estimation, only the first component of Malthus's thinking was correct, the other two having been outmoded by history, rendering his argument 'antiquated in form' (1920, 180). From here, Marshall updated Malthusian doctrine by discussing the nature of population growth and the influence of the 'standard of comfort' on the marriage decision for different classes (1920, 180-85).

This discussion was joined by an improvised history of the English population from the Middle Ages, and it is noticeable how Marshall's sources differ sharply from Malthus's - there is no use of voyagers' accounts to reconstruct an alien way of life (see Bashford and Chaplin, Chapters 3 and 4). But Marshall did use articles in the Statistical Journal (1920, 181n, 184n, 190n, 198n). More plainly, Marshall's history reflected the intellectual specialisation that had occurred since 1798. But there is a final and remarkable disjunction to note between Marshall and Malthus, which relates to Marshall's treatment of 'race vigour' as a crucial variable for the economist to investigate when studying population.

In the Essay, when describing how the positive and negative checks operated in different times and places, Malthus had developed a rich account of populations in terms of their virtues and happiness. He noted, for example, that a 'spirit of independence' existed among the peasantry in England despite the operation of the Poor Laws, which were nevertheless eroding the 'incentives to sobriety and industry, and consequently to happiness' (Malthus 1798 [1986], 33-4). Marshall, however, deployed a different conceptual vocabulary that included 'race', 'blood', and 'vigour'. Like Malthus's earlier pessimism regarding the possibility for a history of population, Marshall suspected that the evidence necessary for a comprehensive 'race history' was simply unavailable:

Race history is a fascinating but disappointing study for the economist: for conquering races generally incorporated the women of the conquered; they often carried with them many slaves of both sexes during their migrations, and slaves were less likely than freemen to be killed in battle or to adopt a monastic life. In consequence nearly every race had much servile, that is mixed blood in it: and as the share of servile blood was largest in the industrial classes, a race history of industrial habits seems impossible. (1920, 195n) 
In the twenty-first century, this is alarming language. More so is Marshall's apparent anxiety over the degeneration of races through selfish prudence:

Thus there are increasing reasons for fearing, that while the progress of medical science and sanitation is saving from death a continually increasing number of the children of those who are feeble physically and mentally; many of those who are most thoughtful and best endowed with energy, enterprise and self-control are tending to defer their marriages and in other ways to limit the number of children whom they leave behind them. The motive is sometimes selfish, and perhaps it is best that hard and frivolous people should leave but few descendants of their own type. But more often it is a desire to secure a good social position for their children. This desire contains many elements that fall short of the highest ideals of human aims, and in some cases, a few that are distinctly base; but after all it has been one of the chief factors of progress, and those who are affected by it include many of those whose children would probably be among the best and strongest of the race. $(1920,201-2)$

If we follow the leading Marshall scholar, however, then this is not, in fact, a story of the dilution of superior races by inferior races. Instead, it is a neo-Lamarckian idea concerning the role of the environment in shaping people (Cook 2013). This would explain why, for example, Marshall made claims such as the following: "vitality is lowered ... by the rapid increase of town life' $(1920,203)$.

For the argument here, however, the exact nature of Marshall's ideas on race are less important than the fact that these concerns are remote from what is found in Malthus. This is not to suggest that Malthus was free of civilisational prejudice, which seems to be intrinsic to stadial history. Rather, the point is that Malthus had originally developed his arguments regarding the principle of population to set out the permanent condition of humans on earth as willed by a benevolent God. As Marshall demonstrated, by the early twentieth century this was no longer a style of argument capable of capturing the economics profession; the intellectual architecture of Malthus's Essay was, as Marshall claimed, 'antiquated'.

\subsection{CONCLUSION}

Malthus's arguments on population may have been old by the time of Marshall, but in their original context they represented a watershed. The crucial feature of that original setting was fear over the nature of political economy as a potential aid to British Jacobins, with Malthus's antiutopian agenda in the Essay perfectly suited for this political situation. 
Yet the science of politics both predated and postdated the French Revolution, and it guaranteed that the reception of Malthus would have more substance and complexity than political expedience. That reception was, on the whole, unkind: excoriated by Romantics on the one side and Owenite radicals on the other, Malthus was also given a cold shoulder by his natural allies at the Edinburgh Review after 1815 for coming down on the wrong side of the Corn Laws debate. In consequence, 50 years after the Essay first appeared it was clear that Malthus's major legacy was to be through the creative reworking of his principle of population.

Two groups did this to the greatest effect: the Ricardians, above all James and John Stuart Mill, who adapted the population principle for a rival version of political economy, and the Christian political economists, who restated Malthus's ideas in more theologically acceptable terms. After mid-century, the rise of 'economics', as exemplified by William Stanley Jevons and Alfred Marshall, saw Malthus read as producing doctrinal claims for the new science, his theodicy forgotten. Simultaneously, the new science demoted population as a topic for analysis as the office of the economist was reconfigured. Henceforth, an intellectual formation such as Malthus's - combining theology, political speculation, and Smith criticism - was simply impossible. In this alien environment, Malthus's legacy withered, and today he has become little more than a name to invoke in public debates over poverty that are conducted without either theology or fear of Jacobinism.

\section{REFERENCES}

Alison, Archibald (1840), The Principles of Population and their Connection with Human Happiness, 2 vols. Edinburgh: William Blackwood and Sons.

Bashford, Alison and Joyce E. Chaplin (2016), The New Worlds of Thomas Robert Malthus: Rereading the Principle of Population. Princeton: Princeton University Press.

Burke, Edmund (1790), 'Reflections on the Revolution in France', reprinted in L.G. Mitchell and William B. Todd (eds) (1989), The Writings and Speeches of Edmund Burke, Volume 8: The French Revolution: 1790-1794. Oxford: Oxford University Press, pp. 53-293.

Chalmers, Thomas (1832), On Political Economy in Connexion with the Moral State and Moral Prospects of Society. Glasgow: Printed for W. Collins.

Claeys, Gregory (1989), Citizens and Saints. Politics and Anti-politics in Early British Socialism. Cambridge: Cambridge University Press.

Clark, J.C.D. (2000), English Society, 1660-1832: Religion, Ideology and Politics During the Ancien Regime (2nd edn). Cambridge: Cambridge University Press. 
Collini, Stefan, Donald Winch, and John Burrow (1983), That Noble Science of Politics: A Study in Nineteenth-century Intellectual History. Cambridge: Cambridge University Press.

Cook, Simon J. (2009), The Intellectual Foundations of Alfred Marshall's Economic Science: A Rounded Globe of Knowledge. Cambridge: Cambridge University Press.

Cook, Simon J. (2013), 'Race and Nation in Marshall's Histories', The European Journal of the History of Economic Thought 20 (6), 940-56.

Corsi, Pietro (1987), 'The Heritage of Dugald Stewart: Oxford Philosophy and Method of Political Economy', Nuncius 2 (2), 89-144.

Cremaschi, Sergio (2014), Utilitarianism and Malthus'Virtue Ethics: Respectable, Virtuous, and Happy. London and New York: Routledge.

Cremaschi, Sergio (2017), 'Theological Themes in Ricardo's Papers and Correspondence', The European Journal of the History of Economic Thought 24 (4), 784-808.

Fetter, Frank Whitson (1953), 'The Authorship of Economic Articles in the Edinburgh Review, 1802-47', Journal of Political Economy 61 (3), 232-59.

Fontana, Biancamaria (1985), Rethinking the Politics of Commercial Society: The Edinburgh Review 1802-1832. Cambridge: Cambridge University Press.

Foucault, Michel (2007), Security, Territory, Population: Lectures at the College de France, 1977-1978. London: Palgrave Macmillan.

Godwin, William (1793), An Enquiry Concerning Political Justice. London: Printed for G.G.J. and J. Robinson.

Godwin, William (1797), The Enquirer. Reflections on Education, Manners, and Literature. London: Printed for G.G.J. and J. Robinson.

Hilton, Boyd (1986), The Age of Atonement: The Influence of Evangelicalism on Social and Economic Thought, 1785-1865. Oxford: Clarendon.

Hilton, Boyd (2006), A Mad, Bad, and Dangerous People? England 1783-1846. Oxford: Oxford University Press.

James, Patricia (1979), Population Malthus: His Life and Times. London: Routledge.

Jevons, William Stanley (1865), The Coal Question: An Inquiry Concerning the Progress of the Nation, and the Probable Exhaustion of our Coal-mines. London and Cambridge: Macmillan and Co.

Jevons, William Stanley (1866), 'Brief Account of a General Mathematical Theory of Political Economy', Journal of the Statistical Society of London 29 (2), 282-7.

Jevons, William Stanley (1870), Elementary Lessons in Logic: Deductive and Inductive. London: Macmillan and Co.

Jevons, William Stanley (1871), The Theory of Political Economy. London: Macmillan and Co.

Jevons, William Stanley (1874), The Principles of Science: A Treatise on Logic and Scientific Method, 2 vols. London: Macmillan and Co.

Jevons, William Stanley (1878), Political Economy. London: Macmillan and Co. Jevons, William Stanley (1882), The State in Relation to Labour. London: Macmillan and Co. 
Kadish, Alon and Keith Tribe (eds) (1993), The Market for Political Economy: The Advent of Economics in British University Culture, 1850-1905. London: Routledge.

King, John E. (2013), David Ricardo. Basingstoke: Palgrave Macmillan.

Malthus, Thomas Robert (1798), 'An Essay on the Principle of Population (1798)', reprinted in E.A. Wrigley and David Souden (eds) (1986), The Works of Thomas Robert Malthus, Volume 1: An Essay on the Principle of Population (1798). New York: Routledge.

Malthus, Thomas Robert (1820), 'Principles of Political Economy', reprinted in E.A. Wrigley and David Souden (eds) (1986), The Works of Thomas Robert Malthus, Volume 5: Principles of Political Economy, Part I. New York: Routledge.

Malthus, Thomas Robert (1826), 'An Essay on the Principle of Population (1826)', reprinted in E.A. Wrigley and David Souden (eds) (1986), The Works of Thomas Robert Malthus, Volume 2: An Essay on the Principle of Population (1798): Part I. New York: Routledge.

Mandler, Peter (1990), 'Tories and Paupers: Christian Political Economy and the Making of the New Poor Law', The Historical Journal 33 (1), 81-103.

Marshall, Alfred (1873), The Future of the Working Classes. Cambridge.

Marshall, Alfred (1920), Principles of Economics: An Introductory Volume. London: Macmillan.

Marshall, Alfred and Mary Marshall (1879), The Economics of Industry. London: Macmillan and Co.

Mill, James (1821), Elements of Political Economy. London: Printed for Baldwin, Cradock and Joy.

Mill, John Stuart (1843), A System of Logic, Ratiocinative and Inductive, being a Connected View of the Principles of Evidence, and the Methods of Scientific Investigation, Volume I. London: John W. Parker.

Mill, John Stuart (1848), 'Principles of Political Economy with Some of Their Applications to Social Philosophy', reprinted in J.M. Robson (ed.) (1965a), The Collected Works of John Stuart Mill, Volume II: The Principles of Political Economy with Some of Their Applications to Social Philosophy, Books I-II. Toronto: University of Toronto Press

Mill, John Stuart (1848), 'Principles of Political Economy with Some of Their Applications to Social Philosophy', reprinted in J.M. Robson (ed.) (1965b), The Collected Works of John Stuart Mill, Volume III: The Principles of Political Economy with Some of Their Applications to Social Philosophy, Books III-IV. Toronto: University of Toronto Press.

Mill, John Stuart (1869a), 'Thornton on Labour and Its Claims', Fortnightly Review 5 (29), 505-18.

Mill, John Stuart (1869b), 'Thornton on Labour and Its Claims, Part II', Fortnightly Review 5 (30), 680-700.

O'Flaherty, Niall (2016), 'Malthus and the "End of Poverty"', in Robert J. Mayhew (ed.), New Perspectives on Malthus. Cambridge: Cambridge University Press, pp. 73-104.

Owen, Robert (1813), A New View of Society. London: Printed for Cadell and Davies. 
Owen, Robert (1834), Moral Physiology: Or, A Brief and Plain Treatise on the Population Question. London: J. Watson.

Paley, William (1802), Natural Theology: Or, Evidences of the Existence and Attributes of the Deity. London: J. Faulder.

Peach, Terry (1993), Interpreting Ricardo. Cambridge: Cambridge University Press.

Pocock, J.G.A. (1994), 'Political Thought in the English Speaking Atlantic, 1760-1790: (ii) Empire, Revolution, and an End of Early Modernity', in J.G.A. Pocock, Gordon J. Schochet, and Lois Schwoerer (eds), The Varieties of British Political Thought, 1500-1800. Cambridge: Cambridge University Press, pp. 238-318.

Rashid, Salim (1977), 'Richard Whately and Christian Political Economy', Journal of the History of Ideas 38 (1), 144-55.

Ricardo, David (1817), 'On the Principles of Political Economy and Taxation', reprinted in Piero Sraffa (ed.) (2005), The Works and Correspondence of David Ricardo, Volume 1: Principles of Political Economy and Taxation. Indianapolis: Liberty Fund.

Southey, Robert (1803), 'Art. XVII. An Essay on the Principles of Population; or, a View of its Past and Present Effects on Human Happiness', The Annual Review and History of Literature 3, 292-301.

Southey, Robert (1816), 'Essay V. On the State of the Poor and the Means Pursued by the Society for Bettering Their Condition, 1816', reprinted in Essays, Moral and Political, Volume I (1832). London: J. Murray, pp. 159-250.

Spence, William (1807), Britain Independent of Commerce. London: Printed by W. Savage for T. Cadell and W. Davies.

Stedman Jones, Gareth (2004), An End to Poverty: A Historical Debate. London: Profile Books.

Stedman Jones, Gareth (2019), 'Malthus, Nineteenth-century Socialism, and Marx', Historical Journal, doi: https://doi.org/10.1017/S0018246X19000165.

Sumner, John Bird (1816), A Treatise on the Records of Creation, 2 vols. London: Printed for J. Hatchard.

Tribe, K. (2015), The Economy of the Word: Language, History, and Economics. Oxford: Oxford University Press.

Walter, Ryan (2015), 'Utilitarianism and Malthus' Virtue Ethics: Respectable, Virtuous and Happy, by Sergio Cremaschi/Malthus: The Life and Legacies of an Untimely Prophet, by Robert J. Mayhew', review of Utilitarian and Malthus' Virtue Ethics: Respectable, Virtuous and Happy, by Sergio Cremaschi, and Malthus: The Life and Legacies of an Untimely Prophet, by Robert J. Mayhew, The European Journal of the History of Economic Thought, 23 (1), 159-64.

Walter, Ryan (2018), 'The Enthusiasm of David Ricardo', Modern Intellectual History 15 (2), 381-409.

Waterman, Anthony (1991), Revolution, Economics and Religion: Christian Political Economy, 1798-1833. Cambridge: Cambridge University Press.

Waterman, Anthony (2004), 'A Cambridge "Via Media", in Anthony Waterman (ed.), Political Economy and Christian Theology since the Enlightenment: Essays in Intellectual History. London: Palgrave Macmillan, pp. 70-87. 
Watts, John (1842), The Facts and Fictions of Political Economists. Manchester: A. Heywood.

Weatherall, David (1976), David Ricardo: A Biography. The Hague: Martinus Nijhoff.

White, M.V. (2005). 'Breaking New Ground: The Significance of WS Jevons's Rent Theory', History of Economics Review 41 (1), 142-56.

White, Michael V. and Takutoshi Inoue (2009), 'Retailing Poisoned Milk? New Evidence on Keynes and Jevons's Hostility to John Stuart Mill', History of Political Economy 41 (3), 419-44.

Winch, Donald (1996), Riches and Poverty: An Intellectual History of Political Economy in Britain, 1750-1834. Cambridge: Cambridge University Press. 